Vol. 2 | No. 1 | 2021 | Hal. 63-68

\title{
OPTIMALISASI PENDIDKAN DI ERA PANDEMI
}

\author{
Priyagung Hartono, Abdullah Musthofainal Akhyar \\ Fakultas Teknik, Universitas Islam Malang \\ *korespondensi email: priyagung@unisma.ac.id
}

\begin{abstract}
ABSTRAK
Pendidikan merupakan suatu pengajaran yang diajarkan oleh guru kepada siswa dengan tujuan untuk mengembangkan kemampuan yang ada pada diri siswa supaya memiliki kepribadian spiritual, dan kecerdasan yang baik, lewat proses belajar yang baik dan teratur. Selain itu beberapa pemberintah daerah telah memutuskan menerapakan kebijakan untuk meliburkan siswa dan mulai menerapkan metode pembelajaran dengan menggunakan sistem online atau daring (dalam jaringan) dan luring (luar jaringan). Di era new normal ini kegiatan proses belajar mengajarakan kembali normal seperti biasanya akan tetapi dengan diiringi berbagai ketentuan yang harus dilaksanakan oleh peserta didik maupun pendidik untuk tetap mengikuti protokol kesehatan yang telah dianjurkan oleh pemerintah. Metode yang digunakan dalam kegiatan ini adalah adalah metode observasi (pengamatan). Pada pembelajaran di masa pandemi ini siswa di tuntut untuk lebih aktif dalam meningkatkan prestasi, terutama dalam penggunaan alat elektronik. Pelaksanaan pengabdian ini berjalan dengan lancer tanpa hambatan dan halangan apapun.
\end{abstract}

Kata Kunci: optimalisasi; pendidikan; pandemi covid

\section{PENDAHULUAN}

Pendidikan merupakan suatu pengajaran yang diajarkan oleh guru kepada siswa dengan tujuan untuk mengembangkan kemampuan yang ada pada diri siswa supaya memiliki kepribadian spiritual, dan kecerdasan yang baik, lewat proses belajar yang baik dan teratur (Zakaria et al., 2019; Arifin \& Tamrin, 2019). Pada kenyataannya problematika pembelajaran di Indonesia saat ini muncul dari akibat adanya virus berasal dari China yang dinamakan dengan Covid-19 (Handarini \& Wulandari, 2020). World Health Organization (2020) menyatakan bahwa virus ini penularannya sangat cepat dan dapat menyebabkan kematian. Akibat dari pendemi Covid-19 membuat pemerintah menyalurkan kebijakan demi menghentikan penularan Covid-19 ini yaitu dengan mengajak masyarakat untuk melaksanakan Physical Distancing atau memberi jarak dengan orang lain sejauh satu meter dan menghindari kerumunan (Ilpaj \& Nurwati, 2020). Selain itu beberapa pemerintah daerah telah memutuskan menerapakan kebijakan untuk meliburkan siswa dan mulai menerapkan metode pembelajaran dengan menggunakan sistem online atau daring (dalam jaringan) dan luring (luar jaringan) (Azizah, 2020; Rahmawati \& Tutiasri, 2021).

Di era new normal ini kegiatan proses belajar mengajarakan kembali normal seperti biasanya akan tetapi dengan diiringi berbagai ketentuan yang harus dilaksanakan oleh peserta didik maupun pendidik untuk tetap mengikuti protokol kesehatan yang telah dianjurkan oleh pemerintah (Bahri \& Arafah, 2020; Wahidah et al., 2020). Selama pembelajaran setidaknya tidak akan normal seperti normal sebelumnya karena selama pandemi tidak ada tugas kelompok yang ada hanya tugas 
mandiri atau individu guna mencegah penularan covid-19 (Abidin et al., 2020; Zakaria et al., 2020).

Sistem pembelajaran daring merupakan salah satu bentuk pembelajaran alternative yang dapat dilaksanakan selama pandemi ini berlangsung. Sistem pembelajaran daring merupakan pembelajaran tanpa tatap muka secara langsung antara guru dan siswa akan tetapi pembelajaran ini melalui online yang menggunakan internet. Guru harus memastikan kegiatan belajar mengajar tetap berjalan seperti biasanya meskipun siswa berada di rumah. Pembelajaran daring bisa menggunakan berbagai macam aplikasi contohnya Google Classroom, Whatsapp Group, Zoom, Ruang Belajar dan masih banyak lagi aplikasi-aplikasilainnya.

Dalam problematika yang sedang terjadi saat ini pendidikan tetap memiliki peran yang sangat penting bagi peserta didik dalam menghadapi pandemi ini. Penelitian ini membahas tentang optimalisasi pendidikan pada masa pandemic dan akan diungkap pula solusinya. Adanya hambatan pada pada proses pembelajaran dapat mempengaruh imotivasi dan minat belajar (Ahmadi dan Widodo S, 1991). Intidarie-learning (daring) sebenarnya terdiri dari dua kata, yaitu " $e$ " yang merujuk pada teknologi elektronik dan "learning" yang merujuk pada tujuanya itu terjadinya belajar. Namun, dalam prakteknya, masih mengedepankan kata " $e$ " dan sedikit melupakan kata "learning" sebagai tujuan utama. Padahal, e-learning (daring) adalah penerapan teknologi informasi dan komputer untuk menciptakan pengalaman belajar (Setiawardhani, 2013). Salah satu unsure kunci menciptakan pengalaman belajar dalam kontekse-learning (daring adalaha danya interaksi antara siswa dengan guru.

Menurut penjelasan dari latar belakang diatas, maka pengabdi berniat untuk mempelajari lebih jauh lagi mengenai apa saja cara mengoptimalkan pendidikan pada masa pandemi di lembaga pendidikan yang ada di Desa Sungairujing.

\section{METODE}

Metode yang digunakan dalam kegiatan ini adalah adalah metode observasi (pengamatan). Metode observasi adalah metode yang dilakukan dengan cara mengamati dan mencatat secara sistematis gejala-gejala yang ada (Riduan et al., 2018). Kegiatan ini merupakan hasil pengamatan secara langsung dari daerah yang ada di jawa timur yaitu Desa Sungairujing, Kecamatan Sangkapura, Pulau Bawean Kabupaten Gresik. Kegiatan KSMTematik ini di khususkan dalam memaksimalkan pendidikan di era pandemi Covid-19 yang dilakukan oleh mahasiswa KSM Tematik UNISMA Kelompok 05.

Adapun tahapan-tahapan yang dilakukan dalam pelaksanaan program yaitu, sebagai berikut (1) Suvei Lapangan, bertujuan untuk mengamati keadaan anak-anak yang sedang melaksanakan pembelajaran, (2) Koordinat dengan Masyarakat, tahapan ini bertujuan meminta izin kepada pihak RT yang bersangkutan terhadap tempat pelaksanaan Mahasiswa KSM tinggal untuk pelaksanakan kegiatan pendampingan belajar, (3) Pelaksaaan program kegiatan, setiap siswa yang berkunjung untuk bimbingan wajib mengunakan masker dan selalu mencuci tangan, (4) Evaluasi Program, dengan tujuan dapat mengetahui apa saja yang menjadi kendala selama kegiatan berlangsung sehingga mahasiswa KSM dapat menemukan solusi bersama dalam mengatasi kendala yang ada.

\section{HASIL DAN PEMBAHASAN}

Work From Home (WFH) merupakan bentuk himbauan dari pemerintah dalam rangka menghentikan penyebaran covid-19. WFH ini hampir di berlakukan pada setiap lembaga termasuk juga dalam lembaga pendidikan. Dalam lembaga pendidikan, WFH merupakan proses Kegiatan Belajar mengajar (KBM) yang biasanya di lakukan di ruangruang kelas secara langsung pada saat ini di berhentikan sementara waktu dengan di gantikan oleh proses belajar mengajar yang dilakukan secara daring/online. 
Peserta didik dan tenaga pendidik tetap melakukan kegiatan belajar mengajar seperti biasanya, akan tetapi di lakukan pada ruang terpisah yaitu di rumah masing-masing. Dan banyak sekali masalah dan kendala yang bemuculan dalam pembelajaran daring ini, diantaranya adalah tidak semua peserta didik memilki fasilitas seperti HP; banyak diantara peserta didik yang hanya memilki HP biasa. Selain itu jika pun ada HP, keterbatasan kuota dan jaringan pun menjadi kendala pada pembelajaran daring ini, karena di lembaga tempat kami KSM ada satu lembaga yang belum masuk sinyal. Dengan adanya kendala-kendala tersebut tentunya akan menghambat proses KBM, dan dapat diartikan bahwa pembelajaran daring belum efektif. Masih banyak kendala-kendala lain yang muncul pada saat sistem online di gunakan yaitu materi yang disampaikan tidak sepenuhnya di pahami oleh peserta didik, peserta didik merasa kebingungan dalam menerima materi yang di sampaikan oleh pendidik.

Dalam kegiatan pembelajaran tentu saja ada tujuan yang harus dicapai oleh peserta didik dan guru. untuk mencapai tujuan tersebut maka diperlukan pelaksanaan pembelajaran yang baik, dalam pelaksanaan pembelajaran terdapat faktor yang dapat mempengaruhinya baik dari faktor pendidik, peserta didik, faktor sarana dan prasarana, dan faktor lingkungan. Ada beberapa problem atau masalah yang didapati dalam kegiatan pembelajaran antara lain keterbatasan sumber belajar, alokasi waktu, dan keterbatasan dana yang tersedia.

Pada kondisi saat ini yang terjadi di lembaga pendidikan yang ada di desa Sungairujing, di masa pandemi siswa di harapkan mampu mengikuti pembelajaran baik melalui daring maupun luring. Dan pastinya harus ada daya dukung dari Orang tua, peralatan HP, Kuota intenet dan buku paket, tapi tidak semua siswa bisa mengikuti pembelajaran karena banyak hal terutama dari orang tua dan kendala sinyal sehingga pembelajaran belum maksimal.

Pada pembelajaran di masa pandemi ini siswa di tuntut untuk lebih aktif dalam meningkatkan prestasi, terutama dalam penggunaan alat elektronik. Dan dari sini lah timbul permasalahan dari kalangan orang tua. Kebijakan yang dikeluarkan oleh pemerintah banyak menimbulkan dampak positif bahkan tak jarang pula dampak negatif yang dikeluhkan oleh peserta didik dan orang tua secara langsung. yang pertama yaitu materi dapat di akses dimanapun dan kapan pun sehingga tidak membutuhkan waktu dan kesempatan yang khusus untuk hadir. Disamping banyaknya manfaat yang di temukan pembelajaran pada masa pandemi ini juga memepunyai sisi negative yaitu banyak siswa dan orang tua yang mengeluhkan ketidak efektifan pembelajaran. Melihat persoalan dan hambatan yang dialami oleh peserta didik memaksa guru harus lebih bijak dalam melakukan proses pembelajaran di khusus pada masa pandemic ini.

Dan kami dari kelompok 05 KSM Tematik UNISMA yang dibantu KSM kelompok lain yang tergabung menjadi KSM domisili Gresik membantu mengoptimalkan pendidikan di masa pandemi desa Sungairujing dengan cara ikut serta ke lembaga pendidikan dalam kegiatan membantu proses pembelajaran dan memberikan bimbingan belajar. 


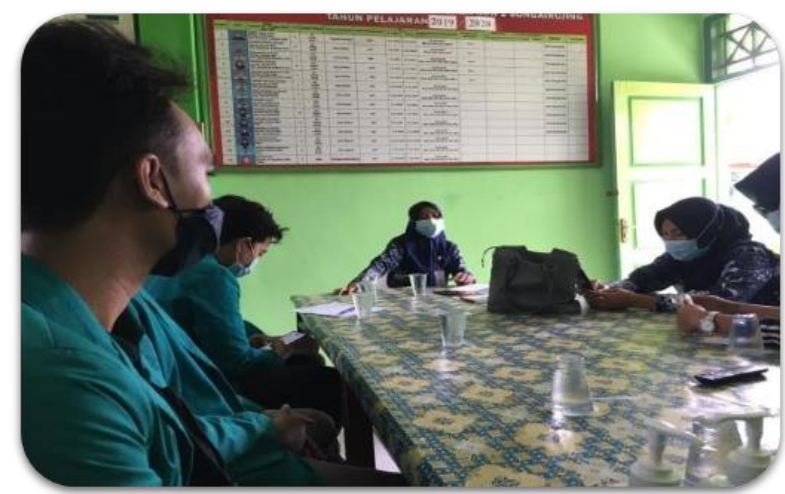

Gambar 1. Konsultasi dengan Kepala Sekolah dan guru mengenai proses pendidikan di era pandemi yang ada di Sekolah tersebut

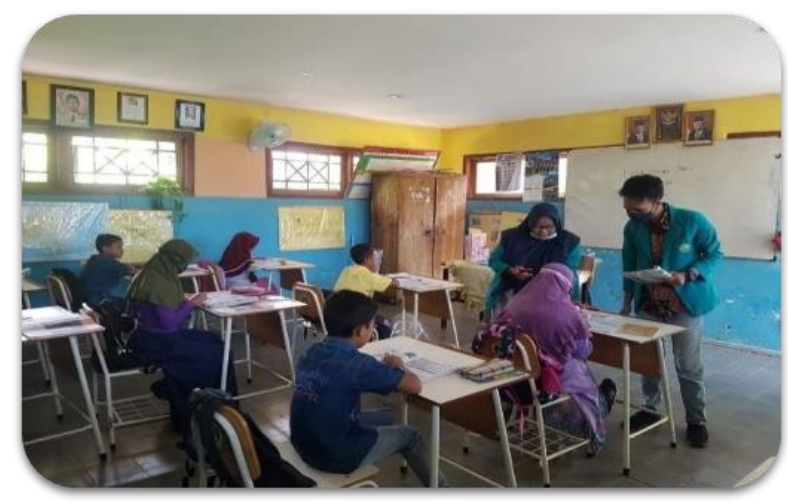

Gambar 2. Membantu bimbingan belajar

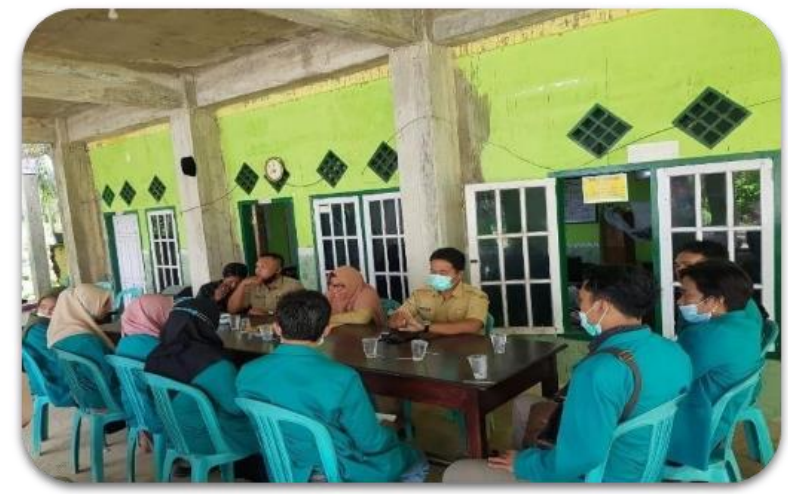

Gambar 3. Konsultasi dengan perangkat desa mengenai optimalisasi pendidikan di era pandemi yang ada di desa Sungairujing

\section{KESIMPULAN}

Pendidikan merupakan suatu pengajaran yang diajarkan oleh guru kepada siswa dengan tujuan untuk mengembangkan kemampuan yang ada pada diri siswa supaya memiliki kepribadian spiritual, dan kecerdasan yang baik, lewat proses belajar yang baik dan teratur. Selain itu beberapa pemberintah daerah telah memutuskan menerapakan kebijakan untuk meliburkan siswa dan mulai menerapkan metode pembelajaran dengan menggunakan sistem online atau daring (dalam jaringan) dan luring (luar jaringan).

Di era new normal ini kegiatan proses belajar mengajarakan kembali normal seperti biasanya akan tetapi dengan diiringi berbagai ketentuan yang harus dilaksanakan oleh peserta didik maupun pendidik untuk tetap mengikuti protokol kesehatan yang telah dianjurkan oleh pemerintah. Peserta didik dan tenaga pendidik tetap melakukan kegiatan belajar mengajar seperti 
biasanya, akan tetapi di lakukan pada ruang terpisah yaitu di rumah masing-masing. Dan banyak sekali masalah dan kendala yang bemuculan dalam pembelajaran daring ini, diantaranya adalah tidak semua peserta didik memilki fasilitas seperti HP; banyak diantara peserta didik yang hanya memilki HP biasa. Ada beberapa problem atau masalah yang didapati dalam kegiatan pembelajaran antara lain keterbatasan sumber belajar, alokasi waktu, dan keterbatasan dana yang tersedia.

Pada pembelajaran di masa pandemi ini siswa di tuntut untuk lebih aktif dalam meningkatkan prestasi, terutama dalam penggunaan alat elektronik. Dan dari sini lah timbul permasalahan dari kalangan orang tua. Kebijakan yang dikeluarkan oleh pemerintah banyak menimbulkan dampak positif bahkan tak jarang pula dampak negatif yang dikeluhkan oleh peserta didik dan orang tua secara langsung. kami dari kelompok 05 KSM Tematik UNISMA dibantu KSM kelompok lain yang tergabung menjadi KSM domisili Gresik membantu mengoptimalkan pendidikan di masa pandemi desa Sungairujing dengan cara ikut serta ke lembaga pendidikan dalam kegiatan membantu proses pembelajaran dan memberikan bimbingan belajar.

Di masa pandemi Covid-19 sekarang ini kami menghimbau dan menyarankan untuk selalu mentaati aturan dan anjuran pemerintah dengan mematuhi protokol kesehatan dengan melaksanakan pola kehidupan baru "New Normal" dan "Social Distancing" atau "Physical Distancing” jaga jarak dan hindari kerumunan selalu memakai masker dan rajin mencuci tangan.

\section{UCAPAN TERIMA KASIH}

Ucapan terima kasih disampaikan kepada Lembaga Pengabdian dan Pemberdayaan Masyarakat Universitas Islam Malang atas kesempatan kami tim peneliti atau mahasiswa KSM-Tematik kelompok 05 memperoleh kesempatan ini. Kepada kepala desa serta jajaranya yaitu Desa Sungairujing, semua lembaga pendidikan yang ada di desa Sungirujing, para wali murid, dan adik-adik yang telah membantu pelaksanaan dan kesuksesan penelitian kami.

\section{DAFTAR RUJUKAN}

Abidin, Z., Hudaya, A., \& Anjani, D. (2020). Efektivitas Pembelajaran Jarak Jauh Pada Masa Pandemi Covid-19. Research and Development Journal of Education, 1(1), 131. https://doi.org/10.30998/rdje.v1i1.7659

Arifin, Z., \& Tamrin, T. (2019). Peningkatan Kompetensi Microcontroller Siswa SMK. Jurnal Inovasi Hasil Pengabdian Masyarakat (JIPEMAS), 2(1), 49-53. https://doi.org/10.33474/jipemas.v2i1.1772

Azizah. (2020). Implementasi Pembelajaran Daring di Era Pandemi Covid-19. StitAlkifayahriau.Ac.Id. https://www.stit-alkifayahriau.ac.id/implementasipembelajaran-daring-di-era-pandemi-covid-19/

Bahri, S., \& Arafah, N. (2020). Analisis Manajemen SDM Dalam Mengembangkan Strategi Pembelajaran Di Era New Normal. Journal of Islamic Education, 1(1), 20-40. https://doi.org/10.31538/tijie.v1i1.2

Handarini, O. I., \& Wulandari, S. S. (2020). Pembelajaran Daring Sebagai Upaya Study From Home (SFH) Selama Pandemi Covid 19. Jurnal Pendidikan Administrasi Perkantoran (JPAP), 8(3), 496-503. https://doi.org/10.1093/fampra/cmy005

Ilpaj, S. M., \& Nurwati, N. (2020). Analisis Pengaruh Tingkat Kematian Akibat Covid-19 Terhadap Kesehatan Mental Masyarakat di Indonesia. Focus : Jurnal Pekerjaan Sosial, 3(1), 16-28. https://doi.org/10.24198/focus.v3i1.28123

Rahmawati, A., \& Tutiasri, R. P. (2021). Edukasi bermain online games secara sehat pada anak-anak usia sekolah dasar. Jurnal Inovasi Hasil Pengabdian Masyarakat (JIPEMAS), 4(1), 69-77. https://doi.org/10.33474/jipemas.v4i1.7841

Riduan, R, S., \& Manaf, N. A. (2018). Kesalahan Kalimat Dalam Teks Laporan Hasil Observasi Siswa Kelas VII SMP Negeri 12 Padang. Jurnal Pendidikan Bahasa Dan Sastra Indonesia (JPBSI), 7(4), 97-103. https://doi.org/10.24036/102337-019883

Setiawardhani, R. T. (2013). Pembelajaran Elektornik (E-learning) dan Internet dalam Rangka Mengoptimalkan Kreativitas Belajar Siswa. Edunomic Jurnal Pendidikan 


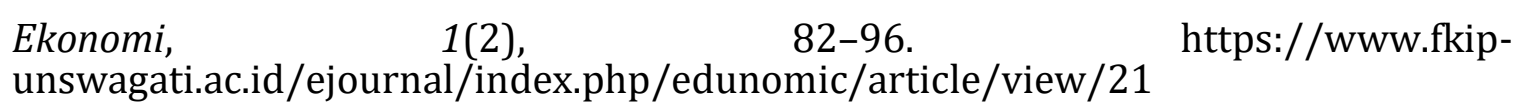

Wahidah, I., Athallah, R., Hartono, N. F. S., Rafqie, M. C. A., \& Septiadi, M. A. (2020). Pandemik COVID-19: Analisis Perencanaan Pemerintah dan Masyarakat dalam Berbagai Upaya Pencegahan. Jurnal Manajemen Dan Organisasi, 11(3), 179-188. https://doi.org/10.29244/jmo.v11i3.31695

World Health Organization (WHO). (2020). Transmisi SARS-CoV-2: implikasi terhadap kewaspadaan pencegahan infeksi (pp. 1-10).

Zakaria, Z., Fadhli, M., \& Arnab, S. (2020). Pelatihan Daring Membuat Topeng Karakter dengan Kilat untuk Meningkatkan Sosial Resiliensi. Prosiding Seminar Nasional $\begin{array}{lll}\text { Pengabdian Masyarakat } & \text { 520-527. }\end{array}$ https://jacips.machung.ac.id/index.php/senam/article/view/26

Zakaria, Z., Setyosari, P., Sulton, \& Kuswandi, D. (2019). The effect of art-based learning to improve teaching effectiveness in pre-service teachers. Journal for the Education of Gifted Young Scientists, 7(3), 531-545. https://doi.org/10.17478/jegys.606963 